\title{
Preparation of Zirconium Phosphate Nanomaterials and Their Applications as Inorganic Supports for the Oxygen Evolution Reaction
}

\author{
Mario V. Ramos-Garcés 1,2 and Jorge L. Colón $1,2, *$ (1) \\ 1 Department of Chemistry, University of Puerto Rico, 17 Ave. Universidad STE 1701, San Juan, \\ PR 00925-2537, USA; mario.ramos1@upr.edu \\ 2 NSF PREM Center for Interfacial Electrochemistry of Energy Materials, University of Puerto Rico, San Juan, \\ PR 00925, USA \\ * Correspondence: jorge.colon10@upr.edu; Tel.: +1-787-402-2015
}

Received: 24 March 2020; Accepted: 23 April 2020; Published: 26 April 2020

\begin{abstract}
Zirconium phosphate $(\mathrm{ZrP})$ nanomaterials have been studied extensively ever since the preparation of the first crystalline form was reported in 1964. $\mathrm{ZrP}$ and its derivatives, because of their versatility, have found applications in several fields. Herein, we provide an overview of some advancements made in the preparation of $\mathrm{ZrP}$ nanomaterials, including exfoliation and morphology control of the nanoparticles. We also provide an overview of the advancements made with $\mathrm{ZrP}$ as an inorganic support for the electrocatalysis of the oxygen evolution reaction (OER). Emphasis is made on how the preparation of the $\mathrm{ZrP}$ electrocatalysts affects the activity of the OER.
\end{abstract}

Keywords: zirconium phosphate; oxygen evolution reaction; electrocatalysis; inorganic nanomaterials

\section{Introduction}

The first report of a crystalline form of zirconium phosphate dates back to 1964 [1]. The chemical composition of this material was determined to be $\mathrm{Zr}\left(\mathrm{HPO}_{4}\right)_{2} \cdot \mathrm{H}_{2} \mathrm{O}$. Later, the first crystal structure of this crystalline $\mathrm{ZrP}$ material was reported in 1969 and then refined in 1977 [2,3]. Its structure consists of a layered arrangement (Figure 1). $\mathrm{Zr}(\mathrm{IV})$ ions align in a near perfect plane bridged by orthophosphate groups, which are $5.3 \AA$ apart from each other, above and below the $\mathrm{Zr}$ ions plane. Each $\mathrm{Zr}$ ion is coordinated by six oxygen atoms from six different phosphate groups, forming an octahedral coordination with the metal center. Three of the oxygen atoms from each phosphate group are coordinated to three different $\mathrm{Zr}$ ions. The fourth oxygen is bonded to a hydrogen atom and points above and below each ZrP layer. The stacking of these layers, which are $6.6 \AA$ thick and $7.6 \AA$ apart from each other, creates a zeolitic cavity with a diameter of $2.61 \AA$ that is occupied by a water molecule $[4,5]$. This description corresponds to that of a phase that has been named $\alpha-\mathrm{ZrP}$, the most extensively studied phase of ZrP. Other phases have been achieved by varying the synthesis protocol and some of these phases will be explained later in this review.

$\mathrm{ZrP}$ acidity and porosity are desired traits for different applications, especially in heterogeneous catalysis [6,7]. Not only that, but these parameters are tunable, expanding the possible applications of $\mathrm{ZrP}$ [8]. Beyond that, the major attractiveness of $\mathrm{ZrP}$ comes from its ability to perform ion-exchange with its acidic phosphate groups. The composite materials that result after ion-exchange differ greatly in their properties when compared to $\alpha-\mathrm{ZrP}$, allowing them to be implemented for several different applications. Ion-exchange in $\mathrm{ZrP}$ occurs at the Brönsted acid groups (P-OH) which are also present at the surface of the nanoparticles, opening another pathway for the modification of this material: surface modification [9-11]. These composite materials have been used for several applications including 
photocatalysis [12,13], drug delivery [14-17], amperometric biosensors [18-20], catalysis [7,21-26], flame retardancy [27-29], and others. We encourage the reader to also see other recent reviews on the topic of the synthesis of $\mathrm{ZrP}$ and its applications [7,8,30,31].

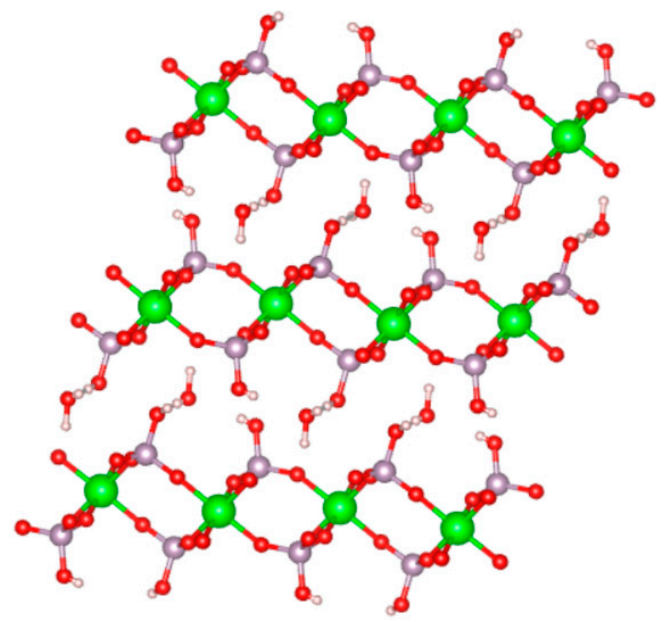

Figure 1. Ball and stick model of the structure of $\alpha-\mathrm{ZrP}$.

\section{Synthesis and Preparation of ZrP Nanomaterials}

\section{1. $\alpha-Z r P$}

Clearfield and Stynes were able to synthesize the first crystalline $\mathrm{ZrP}(\alpha-\mathrm{ZrP})$ by refluxing amorphous gels in phosphoric acid [1]. Later, a hydrothermal method and a synthesis with HF were reported [32]. The method used for the synthesis of $\alpha-\mathrm{ZrP}$ has a direct impact on the size and shape of the resulting nanoparticles. This is another advantage as we can adjust these parameters depending on the application while still retaining the main characteristics of $\alpha$-ZrP. More specifically, the concentrations of reactants, temperature during synthesis, pressure, and use of complexing agents have been found to have an effect on the aspect ratios of the nanoparticles [33].

Sun et al. reported the synthesis of $\alpha-\mathrm{ZrP}$ nanoparticles through three different methods and characterized the materials [34]. The first method consisted of mixing $\mathrm{ZrOCl}_{2} \cdot 8 \mathrm{H}_{2} \mathrm{O}$ with phosphoric acid $\left(\mathrm{H}_{3} \mathrm{PO}_{4}\right)$ at varying concentrations. Namely, 3, 6, 9, and $12 \mathrm{M} \mathrm{H}_{3} \mathrm{PO}_{4}$ at $100{ }^{\circ} \mathrm{C}$ and $24 \mathrm{~h}$. The second method consisted of mixing $\mathrm{ZrOCl}_{2} \cdot 8 \mathrm{H}_{2} \mathrm{O}$ with $\mathrm{H}_{3} \mathrm{PO}_{4}$ (at the same concentrations as in approach 1) in a Teflon ${ }^{\circledR}$ pressure vessel and heating each reaction at $200{ }^{\circ} \mathrm{C}$ for $24 \mathrm{~h}$. The final approach consisted of mixing $\mathrm{ZrOCl}_{2} \cdot 8 \mathrm{H}_{2} \mathrm{O}$ with $3.0 \mathrm{M} \mathrm{H}_{3} \mathrm{PO}_{4}$ in a Teflon ${ }^{\circledR}$ flask. HF was added so that the molar ratios of $\mathrm{F} / \mathrm{Zr}$ were $1,2,3$, and 4 .

The authors of this study observed that, for method 1 , the crystallinity and aspect ratio increase as the $\mathrm{H}_{3} \mathrm{PO}_{4}$ concentration increases. The resulting nanoplatelets had sizes ranging from $\sim 60 \mathrm{~nm}$ to $\sim 200 \mathrm{~nm}$. The nanoplatelets that resulted from method 2 had an enhanced crystallinity when compared to those from method 1. Moreover, the aspect ratio increases and the size of the nanoplatelets now range from $\sim 400$ to $\sim 1200 \mathrm{~nm}$ as the concentration of $\mathrm{H}_{3} \mathrm{PO}_{4}$ increases. Finally, the $\alpha$ - $\mathrm{ZrP}$ platelets obtained from method 3 have an even higher crystallinity than the nanoplatelets from method 2. An increase in the aspect ratio is also observed and the sizes range from $\sim 2000$ to over $\sim 4000 \mathrm{~nm}$. The scanning electron microscopy (SEM) images of these samples are shown in Figure 2. Recently, Contreras-Ramirez et al. made a detailed study on how the synthesis method and reaction conditions affect the structural order and crystallinity of $\alpha$-ZrP. In their study, the authors used synchrotron X-ray atomic pair distribution function (PDF) analysis to observe the changes in the structural order caused from the different methods and conditions [35]. 


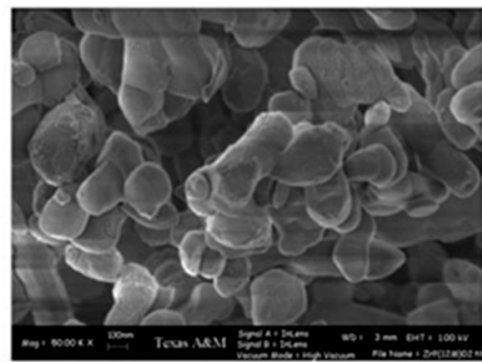

A

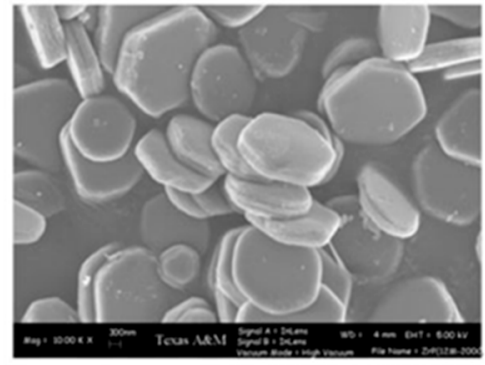

B

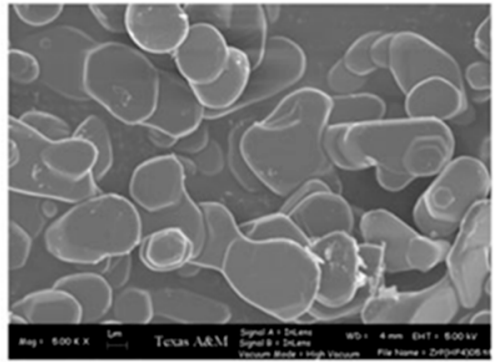

C

Figure 2. SEM images of $\alpha$-ZrP prepared by (A) reflux method $\left(12 \mathrm{M} \mathrm{H}_{3} \mathrm{PO}_{4}\right)(\mathbf{B})$ hydrothermal method $\left(9 \mathrm{M} \mathrm{H}_{3} \mathrm{PO}_{4}\right)(\mathrm{C}) \mathrm{HF}$ method $(\mathrm{F} / \mathrm{Zr}=4)$. [34] -Adapted by permission of The Royal Society of Chemistry on behalf of the Centre National de la Recherche Scientifique, 2007.

The reflux, hydrothermal, and HF method for the synthesis of $\alpha-\mathrm{ZrP}$ have been the most widely used methods throughout the decades. However, other methods have been reported in the literature such as precipitation with oxalic acid and by liquid-phase deposition [36-38]. Pica et al. reported the synthesis via an alcohol intercalation/deintercalation method [39]. $\alpha-\mathrm{ZrP}$ was prepared by dissolving zirconium propionate in different anhydrous alcohols (ethanol, propanol, and butanol) and adding $\mathrm{H}_{3} \mathrm{PO}_{4}$ at different $\mathrm{H}_{3} \mathrm{PO}_{4} / \mathrm{Zr}$ molar ratios $(2,4$, and 6). This synthesis procedure results in transparent gels. Characterization of these gels by X-ray powder diffraction (XRPD) shows only one well defined peak in all diffractograms corresponding to (002) planes of $\mathrm{ZrP}$. This corresponds to the interlayer distance and it was found to vary depending on the alcohol used during synthesis. More specifically, the interlayer distance was found to be $14.4 \AA$ when ethanol was used, $16.1 \AA$ for propanol, and 18.6 $\AA$ for butanol. This highlights that the alcohols are contained within the layers of ZrP. The TEM images of these samples reveal that the resulting nanoparticles are hexagonal shaped and have regular planar sizes of $\sim 40 \mathrm{~nm}$, independent of which alcohol was used. When the gels are dried at $60^{\circ} \mathrm{C}$ until complete solvent evaporation, a white powder is obtained. The XRPD diffractograms for all samples shows a shift in the first peak to $d=7.56 \AA$, indicating the formation of $\alpha$-ZrP. The authors found that the crystallinity of the resulting $\alpha-\mathrm{ZrP}$ nanoparticles was dependent on the $\mathrm{H}_{3} \mathrm{PO}_{4} / \mathrm{Zr}$ molar ratio and increases with increasing ratio. The transmission electron microscopy (TEM) images for the samples prepared with an $\mathrm{H}_{3} \mathrm{PO}_{4} / \mathrm{Zr}$ ratio of 6 show that the nanoparticles kept a more or less hexagonal morphology and the distribution of planar sizes increased to a $\sim 30-200 \mathrm{~nm}$ range.

Highly crystalline $\alpha$-ZrP was reported with a new method by using a minimal solvent synthesis procedure [40]. By adding $\mathrm{H}_{3} \mathrm{PO}_{4}$ to powder $\mathrm{ZrOCl}_{2} \cdot 8 \mathrm{H}_{2} \mathrm{O}$ with a $\mathrm{H}_{3} \mathrm{PO}_{4} / \mathrm{Zr}$ molar ratio of two, $\alpha-\mathrm{ZrP}$ was successfully obtained. Moreover, if the $\mathrm{H}_{3} \mathrm{PO}_{4} / \mathrm{Zr}$ molar ratio is increased to three, $\alpha-\mathrm{ZrP}$ with enhanced crystallinity is obtained. The SEM images of $\alpha-\mathrm{ZrP}$ prepared with a $\mathrm{H}_{3} \mathrm{PO}_{4} / \mathrm{Zr}$ molar ratio of three show that the cross-sectional dimensions of the nanoplatelets are in the range of $\sim 100-500 \mathrm{~nm}$ with a thickness of $\sim 40-66 \mathrm{~nm}$. This method introduces a greener and milder option for the synthesis of highly crystalline $\alpha-\mathrm{ZrP}$ as no excess of $\mathrm{H}_{3} \mathrm{PO}_{4}$ is required and/or the use of hazardous HF.

\subsection{ZrP Exfoliation}

The process of separating the layers of a bulk layered material is known as exfoliation. This process can be achieved by a variety of methods and has been extensively studied for several layered materials [41]. The two-dimensional materials (2D) of nanosheets or few layered nanosheets that result after exfoliation have been shown to have several advantages over their bulk systems [42]. Enhancement in conductivity, surface area, mechanical flexibility, optical transparency, and other properties make these exfoliated materials suitable for application in different areas, such as electrocatalysis, electronics, energy storage, and others [42].

$\mathrm{ZrP}$ has been successfully exfoliated and its nanosheets used for different applications [6,21,43-50]. The most widely used strategy for $\mathrm{ZrP}$ exfoliation consists of the intercalation of small amine cations 
that can easily displace the protons from the phosphate groups in an acid-base reaction and enter the interlayer space [51]. The mechanism of this process is said to be the formation of an amine double layer in the interlayer space, leading to exfoliation due to cation-cation repulsions [44]. Kaschak et al. studied the exfoliation of $\mathrm{ZrP}$ with tetra- $n$-butylammonium hydroxide $\left(\mathrm{TBA}^{+} \mathrm{OH}^{-}\right)$[52]. The authors estimated the $\mathrm{TBA}^{+}$diffusion rate within the $\mathrm{ZrP}$ galleries from the time required to achieve a constant expansion rate and the distance travelled in this time. The intercalation rates determined suggests a first-order process that depends on the opening of the interlayer at the edges of the nanoplatelets. As the exfoliation of $\mathrm{ZrP}$ is known to produce hydrolysis products, Kaschak et al. studied this process by atomic force microscopy (AFM) and TEM. Results show that the hydrolysis reaction occurs from the edges inward and the percent hydrolysis increases as a function of time. The hydrolysis process after $1 \mathrm{~h}$ was monitored by varying the temperature of the reaction. It was found that the hydrolysis percent varied drastically with temperature. For both semi-crystalline and micro-crystalline $\mathrm{ZrP}$, the rate of hydrolysis during exfoliation is essentially zero at $0{ }^{\circ} \mathrm{C}$. However, at higher temperatures, the percent hydrolysis is noticeable and increases with increasing temperature.

$\mathrm{ZrP}$ has also been successfully exfoliated via a melt-compounding method [53]. Here, $\mathrm{ZrP}$ is first intercalated with diglycolamine (DGA). After intercalation, the product was dried and ground into fine powders and subsequently mixed with maleic anhydride grafted polyolefin elastomer (POE-g-MA). The mixtures were then exfoliated with melt compounding.

Another method that has been reported for the exfoliation of $\mathrm{ZrP}$ is the assisted exfoliation with ionic liquids [54]. Herein, $\alpha-\mathrm{ZrP}$ is first intercalated with small molecules such as DGA. Then, the DGA intercalated $\mathrm{ZrP}$ is mixed with the ionic liquid 1-methyl-3- $n$-octylimidazolium bromide [OMIm]Br and ultrasonicated for 30-60 min. After product collection and characterization, the authors noticed the successful exfoliation of ZrP. The initial intercalation step is crucial as it helps in expanding the interlayer spacing and weakens the H-bonding between the layers. DGA is thought to attach to the $\mathrm{ZrP}$ through its amine end while the rest of the molecule is a small polar chain that can attract OMIm cations. Hence, it is believed that OMIm enters the interlayer through a cation-lone pair attraction, forming highly charged surfaces, which leads to the complete exfoliation of $\alpha-\mathrm{ZrP}$ and stabilization of the nanosheets in ionic liquids.

Recently, an ZrP exfoliation procedure using Tris-(hydroxymethyl)-aminomethane (Tris) was reported [48]. For this, $\alpha-\mathrm{ZrP}$ is added to a Tris buffer solution and the mixture is ultrasonicated for $20 \mathrm{~min}$. This method introduces the substitution of commonly used organic strong bases to a more environmentally friendly, less basic, and non-toxic Tris exfoliating agent.

After exfoliation, some exfoliating agents can be displaced with another cationic species if the latter is put in contact with a suspension of the exfoliated $\mathrm{ZrP}$ nanoparticles. To obtain the protonated ZrP nanosheets, producing the Brönsted acid groups, a follow-up method with an acid can be performed [21]. The exfoliation of ZrP has also been accomplished by using alkanol amines and other wet methods $[55,56]$.

\subsection{ZrP with Different Morphologies}

By adding fluoride anions $\left(\mathrm{F}^{-}\right)$in the synthesis of $\alpha-\mathrm{ZrP}$ using the minimal solvent synthesis procedure, crystal growth along the a-axis is favored [40]. The result of this is the formation of $\alpha-\mathrm{ZrP}$ particles with rod-like morphology. The addition of different $\mathrm{F}^{-}$sources, such as $\mathrm{NaF}$ and $\mathrm{NH}_{4} \mathrm{~F}$, and keeping the synthesis temperature and duration at $100{ }^{\circ} \mathrm{C}$ and $24 \mathrm{~h}$, respectively, results in highly crystalline rod-like particles along with platelet-like structures. The observed platelets have sizes around $1 \mu \mathrm{m}$ and the rods are $4-10 \mu \mathrm{m}$ in length. Reaction time studies show that increasing the duration of the reaction favors the formation of the rods over the platelet structures (Figure 3). It is believed that the formation of zirconium-fluoro complexes on the (001) crystal planes due to selective absorption of the fluoride ions is the cause of the favored a-axis crystal growth. 

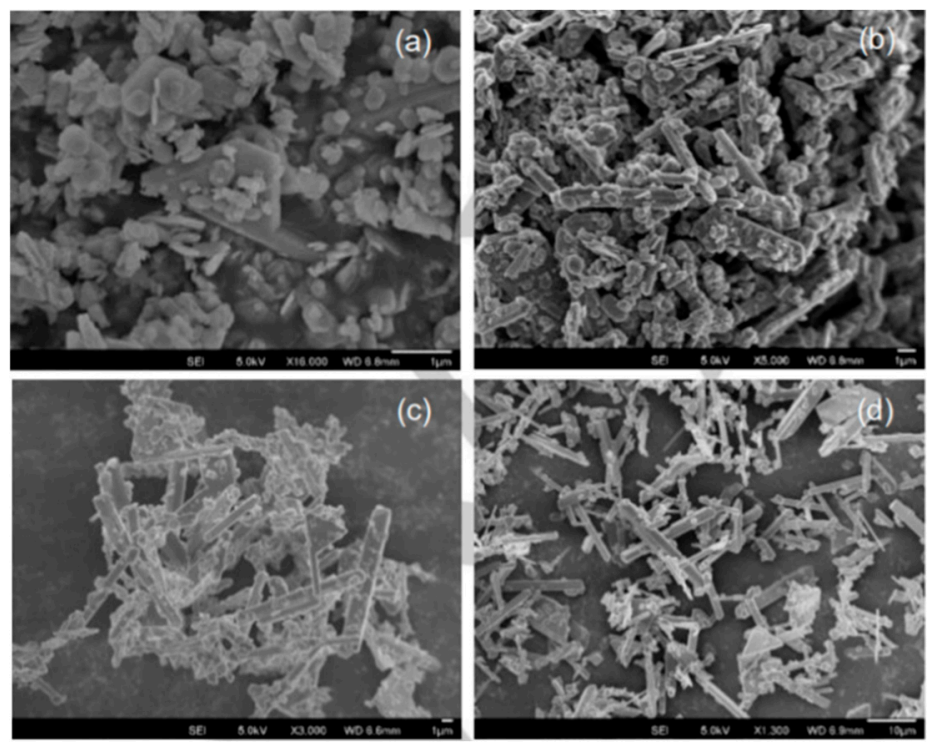

Figure 3. SEM images of $\alpha$-ZrP prepared by the minimal solvent synthesis method with $\mathrm{F}^{-}$ions at different reaction times; (a) $1 \mathrm{~h} \mathrm{(b)} 4 \mathrm{~h} \mathrm{(c)} 8 \mathrm{~h}$ and (d) $96 \mathrm{~h}$. Reproduced from [40], with permission from John Wiley and Sons, 2017.

Pica et al. reported that cube-like $\mathrm{ZrP}$ nanoparticles can be obtained with the alcohol intercalation/ deintercalation procedure [57]. When the gels are dried at $120^{\circ} \mathrm{C}$ instead of $60^{\circ} \mathrm{C}$, a different crystal structure is obtained. The phase resulting from this synthesis method that produces cube-like $\mathrm{ZrP}$ was found to be similar to a previously reported phase of $\mathrm{ZrP}$ called $\tau-\mathrm{ZrP}$, with a few discrepancies. For this reason, this new phase was labelled as $\tau^{\prime}$-ZrP. This phase was described to have $\mathrm{Zr}$ octahedrally coordinated by six $\mathrm{HPO}_{4}$ tetrahedra, forming eight-membered rings. These eight-membered rings contain two $\mathrm{P}-\mathrm{OH}$ groups pointing to the same side of the $\mathrm{Zr}$ plane. The 3D structure of $\tau^{\prime}$ - $\mathrm{ZrP}$ consists of the packing of these planes perpendicularly to each other (Figure 4). These authors reported that the formation of $\tau^{\prime}$-ZrP from $\alpha$ - ZrP prepared by this method is possible by heating $\alpha$ - $\mathrm{ZrP}$ at $120^{\circ} \mathrm{C}$. It was also observed that the transformation of $\tau^{\prime}-\mathrm{ZrP}$ to $\alpha-\mathrm{ZrP}$ occurs at room temperature. However, when both products are washed with the alcohol used during synthesis, neither transformation occurs. It is believed that the presence of free $\mathrm{H}_{3} \mathrm{PO}_{4}$ catalyzes these transformations. Hence, washing the products removes the extra $\mathrm{H}_{3} \mathrm{PO}_{4}$ present and stabilizes the phases, preventing the reversibility between $\tau^{\prime}$ - $\mathrm{ZrP}$ and $\alpha-\mathrm{ZrP}$. ZrP derivatives have also been successfully prepared with cube morphologies [58].

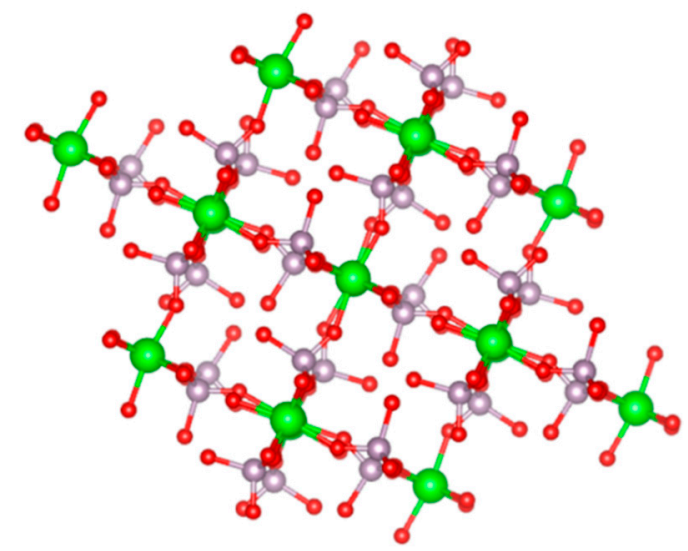

Figure 4. Ball and stick model of the structure of $\tau^{\prime}-\mathrm{ZrP}$ [57].

$\mathrm{ZrP}$ has also been successfully synthetized with sphere morphologies. Zhang et al. reported the synthesis of microspherical $\mathrm{ZrP}$ by a colloid mill procedure [59]. For this, $\alpha-\mathrm{ZrP}$ is first prepared by 
dissolving $\mathrm{ZrOCl}_{2} \cdot 8 \mathrm{H}_{2} \mathrm{O}$ in $\mathrm{HCl}$ and added along with a $\mathrm{H}_{3} \mathrm{PO}_{4} / \mathrm{HCl}$ acid solution to a colloid mill at $3000 \mathrm{rpm}$ for $2 \mathrm{~min}$. The resulting solution is then collected with $15 \mathrm{M} \mathrm{H}_{3} \mathrm{PO}_{4}$ and refluxed at $363 \mathrm{~K}$ for $72 \mathrm{~h}$. To prepare the microspheres, the precipitate of the above solution is redispersed in $\mathrm{H}_{2} \mathrm{O}$ to form a precursor slurry. This slurry is then fed into an atomizer and an aerosol dispersion is generated within the tubular reactor of the spray-drying apparatus. After the shaping process with set parameters, the collected $\alpha-\mathrm{ZrP}$ microspheres showed diameters in the range of 5-45 $\mu \mathrm{m}$. The authors observed that calcination of the microspheres does not change the morphology.

The synthesis of smaller microspheres was reported by Tarafdar et al. [60]. These microspheres are mesoporous in nature and have diameters ranging from 1-3 $\mu \mathrm{m}$. To prepare these mesoporous spheres, $\mathrm{ZrOCl}_{2} \cdot 8 \mathrm{H}_{2} \mathrm{O}$ is mixed with $\left(\mathrm{NH}_{4}\right)_{2} \mathrm{CO}_{3}$ and $\left(\mathrm{NH}_{4}\right)_{2} \mathrm{HPO}_{4}$ in $\mathrm{H}_{2} \mathrm{O}$. Tetradecyltrimethylammonium bromide (TTABr) is added as a surfactant and the mixture is heated at $80^{\circ} \mathrm{C}$ for $3 \mathrm{~d}$, followed by aging in an autoclave at $90^{\circ} \mathrm{C}$ for $2 \mathrm{~d}$, and at $120^{\circ} \mathrm{C}$ for $1 \mathrm{~d}$. The obtained product is then calcined at $540{ }^{\circ} \mathrm{C}$ for $6 \mathrm{~h}$.

The synthesis of spherical $\mathrm{ZrP}$ has also been reported using a microwave-assisted hydrothermal method [61]. More specifically, $\mathrm{ZrOCl}_{2} \cdot 8 \mathrm{H}_{2} \mathrm{O}$ is mixed with $\mathrm{H}_{3} \mathrm{PO}_{4}$ and placed in a microwave oven for $30 \mathrm{~min}$ at $120^{\circ} \mathrm{C}$. The obtained gel is then washed and dried at $80^{\circ} \mathrm{C}$ for $24 \mathrm{~h}$. Characterization with XRPD confirms that the product is $\alpha$-ZrP. SEM images elucidate that the spheres are composed of an agglomeration of smaller $\alpha$-ZrP nanoparticles.

$\mathrm{ZrP}$ has also been prepared with a flower-like morphology by a solid-state synthesis [62]. For this, $\mathrm{ZrOCl}_{2} \cdot 8 \mathrm{H}_{2} \mathrm{O}$ is mixed $\mathrm{Na}_{3} \mathrm{PO}_{4}$ and ground together for $50 \mathrm{~min}$. Then, the mixture is autoclaved at $80^{\circ} \mathrm{C}$ for $96 \mathrm{~h}$. XRPD confirms that $\alpha-\mathrm{ZrP}$ was prepared and the SEM images indicate that these flower-like particles have dimensions of 5-7 $\mu \mathrm{m}$. These flowers are composed of smaller $\mathrm{ZrP}$ nanosheets of $\sim 100 \mathrm{~nm}$ in thickness. It was found that extending the reaction time beyond $96 \mathrm{~h}$ destroys the flower-like morphology and that it is only obtained at $80^{\circ} \mathrm{C}$. The phosphate precursor also plays an important role, as it was observed that using an alternate source did not produce the flower-like structure.

$\mathrm{ZrP}$ hexagonal prisms (Figure 5) were prepared by dissolving $\mathrm{ZrOCl}_{2} \cdot 8 \mathrm{H}_{2} \mathrm{O}$ in formamide, mixing

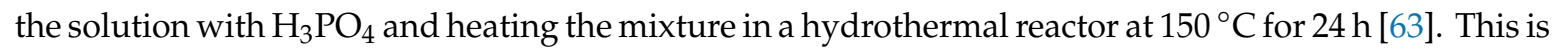
followed by aging at predetermined temperatures $\left(60,80,100\right.$, and $\left.150{ }^{\circ} \mathrm{C}\right)$ for 1 week. The prisms grow due to the selective adsorption of ammonium cations (from the solvent) onto the layer surfaces that are parallel to the precipitated (001) crystal plane. This allows the growth of layers on top of each other. Further characterization shows that these $\mathrm{ZrP}$ prisms are $\mathrm{NH}_{4} \mathrm{ZrH}\left(\mathrm{PO}_{4}\right)_{2}$, which has an interlayer distance of $11.18 \AA$. Treating these prisms with acid converts them into $\alpha$-ZrP. However, the prismatic structure is destroyed during this conversion. It is worth noting that $\mathrm{ZrP}$ and some derivatives have also been reported with different morphologies other than the platelet-like structures $[64,65]$. Table 1 summarizes the various methods of $\mathrm{ZrP}$ nanoparticle preparation reported herein.

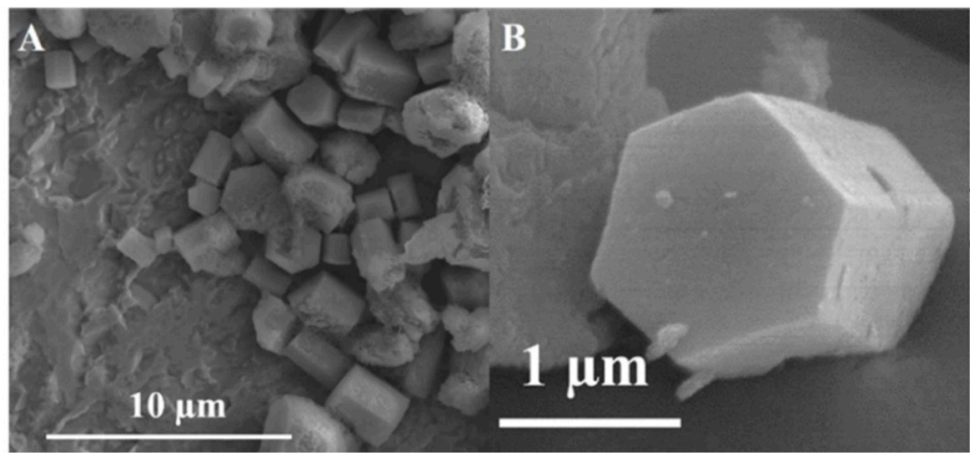

Figure 5. SEM images (A,B) of the prepared ZrP prisms. Reproduced from [63], with permission from the American Chemical Society, 2020. 
Table 1. Summarizing table on the different preparation methods of $\mathrm{ZrP}$ nanoparticles.

\begin{tabular}{cccc}
\hline Method & Morphology & Size (nm) & Reference \\
\hline Reflux & Hexagonal platelets & $60-200$ & {$[34]$} \\
HF & Hexagonal platelets & $2000-4000$ & {$[34]$} \\
Hydrothermal & Hexagonal platelets & $400-1200$ & {$[34]$} \\
Oxalic acid precipitation & Hexagonal platelets & $2000-3000$ & {$[37]$} \\
Liquid-phase deposition & Hexagonal platelets & $2000-3000$ & {$[38]$} \\
Minimal solvent & Hexagonal platelets & $30-200$ & {$[39]$} \\
Minimal solvent $\left(\right.$ with $\left.\mathrm{F}^{-}\right)$ & Hexagonal platelets & $100-500$ & {$[40]$} \\
Alcohol intercalation/deintercalation $\left(60^{\circ} \mathrm{C}\right)$ & Rod-like & $4000-10,000$ & {$[40]$} \\
Colloid mill procedure & Cube-like & $100-500$ & {$[57]$} \\
Tarafdar et al. & Spheres & $5000-445,000$ & {$[59]$} \\
Microwave-assisted hydrothermal & Spheres & $1000-3000$ & {$[60]$} \\
Mu et al. & Spheres & $1000-3000$ & {$[61]$} \\
Yu et al. & Flower-like & $5000-7000$ & {$[62]$} \\
\hline
\end{tabular}

\subsection{Intercalation of Guest Species into $\mathrm{ZrP}$}

Whittingham defined intercalation (in chemistry) as "the reversible insertion of guest species into a lamellar host structure with maintenance of the structure features of the host" [66]. The zeolitic cavity with a diameter of $2.61 \AA$ in $\alpha$-ZrP impedes the direct intercalation of species with larger dimensions, hence the intercalation of these species is not significant and/or they are exchanged at very slow rates [5,67-69]. To circumvent this problem, pre-intercalation methods such as the intercalation of sodium cations or small alkyl amines into $\alpha-\mathrm{ZrP}$ (producing expanded $\mathrm{ZrP}$ phases) are commonly performed as the first step for the intercalation of the intended guest species [69,70]. However, these pre-intercalation methods typically result in the co-intercalation of various species, hindering the analysis of experimental results.

To address this, Martí and Colón reported in 2003 a new method for the direct intercalation of large metal complexes that does not require a pre-intercalation step [13]. This method consists of using a highly hydrated phase of zirconium phosphate, namely, $\mathrm{Zr}\left(\mathrm{HPO}_{4}\right)_{2} \cdot 6 \mathrm{H}_{2} \mathrm{O}(\theta-\mathrm{ZrP})[13]$. $\theta-\mathrm{ZrP}$ can be prepared by using a reflux method that results in a material with the same type of layers as $\alpha$-ZrP, but with an interlayer distance of $10.4 \AA$, instead of $7.6 \AA$ [71]. The increased interlayer distance is due to the six water molecules per formula unit in $\theta-\mathrm{ZrP}$, in contrast with $\alpha-\mathrm{ZrP}$ that only has one [72]. When $\theta-\mathrm{ZrP}$ is allowed to dry, it converts back to $\alpha-\mathrm{ZrP}$. This can be confirmed with XRPD as the first diffraction peak at $2 \theta=8.6^{\circ}\left(\mathrm{d}_{002}=10.4 \AA\right)$ for $\theta-\mathrm{ZrP}$, which corresponds to the interlayer distance, shifts towards $11.6^{\circ}\left(\mathrm{d}_{002}=7.6 \AA\right)$ when this material dehydrates. Hence, determining if an intercalation was successful is trivial, as the XRPD analysis of a dry intercalation product should yield a first diffraction peak with a distance greater than $7.6 \AA$ [14].

In their study, Martí and Colón intercalated the luminescent metal complex tris(2,2'-bipyridyl ruthenium(II) $\left(\left[\mathrm{Ru}(\mathrm{bpy})_{3}\right]^{2+}\right.$ ) by direct ion exchange into $\mathrm{ZrP}$, using $\theta-\mathrm{ZrP}$ (Figure 6) [13]. The intercalated product shows an increase in the interlayer distance to $15.2 \AA$, and $\left[\mathrm{Ru}(\mathrm{bpy})_{3}\right]^{2+}$ retains its structural integrity. This method of intercalation via direct ion exchange in $\mathrm{ZrP}$ is by an ion exchange reaction with the protons in the Brönsted acid groups $(\mathrm{P}-\mathrm{OH})$. As the intercalation proceeds, the intercalant enters the interlayer space though the edges and diffuses into the center of the solid [73]. The direct intercalation of several guest species into $\theta-\mathrm{ZrP}$ has been successfully used to produce composite materials for different applications $[18,20,74-79]$. 


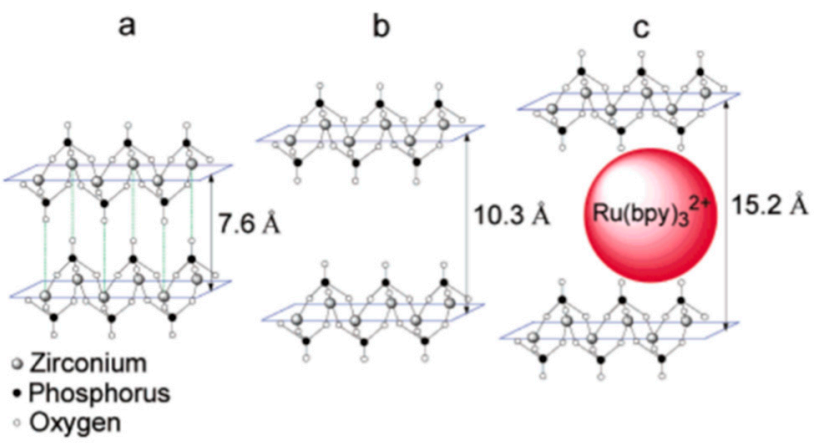

Figure 6. Schematic representation of (a) $\alpha-\mathrm{ZrP}$ (b) $\theta-\mathrm{ZrP}$ and (c) $\left[\mathrm{Ru}(\mathrm{bpy})_{3}\right]^{2+}$-exchanged $\mathrm{ZrP}$. Reproduced from [13], with permission from the American Chemical Society, 2003.

\section{ZrP Nanomaterials as Support for OER Active Species}

The OER is the oxidative half reaction of water electrolysis, consisting of the four-electron oxidation of water to produce oxygen and protons. In alkaline media, the reaction mechanism of the OER is described with four oxidation steps (Equations (1)-(4), where AS stands for active site) [80]. The first step is the one electron oxidation of a hydroxide ion, followed by a proton-coupled electron transfer, giving an oxygen atom adsorbed onto the AS. The third step is a nucleophilic attack coupled to a one electron oxidation, producing an hydroperoxide species adsorbed onto the AS. The fourth and final step is a second proton-coupled electron transfer step and subsequent product removal from the AS. It is an important half-cell reaction in many energy-related schemes such as $\mathrm{CO}_{2}$ reduction, metal-air batteries, and photoelectrochemical (PEC) water splitting [81]. However, the OER suffers from considerable overpotential losses due to its sluggish kinetics, hindering the large-scale implementation of sustainable clean energy production [82]. Benchmarking studies of electrocatalytic systems for the OER have suggested that their overpotentials have plateaued, limiting the efficiency of future PEC and other technological devices [83-85]. In these studies, all the catalysts in alkaline solution require overpotentials of $0.30-0.50 \mathrm{~V}$ to drive the reaction at a current density of $10 \mathrm{~mA} / \mathrm{cm}^{2}$. This may suggest common mechanistic limitations and new strategies are needed in order to produce catalysts that are more efficient and more stable for this reaction.

$$
\begin{gathered}
\mathrm{AS}+\mathrm{OH}^{-} \rightarrow \mathrm{e}^{-}+\mathrm{AS}-\mathrm{OH} \\
\mathrm{AS}-\mathrm{OH} \rightarrow \mathrm{e}^{-}+\mathrm{H}^{+}+\mathrm{AS}-\mathrm{O} \\
\mathrm{AS}-\mathrm{O}+\mathrm{OH}^{-} \rightarrow \mathrm{e}^{-}+\mathrm{AS}-\mathrm{OOH} \\
\mathrm{AS}-\mathrm{OOH} \rightarrow \mathrm{e}^{-}+\mathrm{AS}+\mathrm{H}^{+}+\mathrm{O}_{2}
\end{gathered}
$$

Catalysis can be improved in two ways: increasing the number of actives site in a system or increasing the intrinsic activity of active sites (Figure 7) [86]. This catalytic improvement can be accomplished by a variety of experimental methods such as intercalation/confinement, supporting active species onto supports, nanostructuring, and many others. $\mathrm{ZrP}$ high thermal and chemical stability, as well as its electrochemical inertness, makes it a suitable material to be studied as an OER support. The electrochemical inertness is of outmost importance for a material to be considered a potential support and $\mathrm{ZrP}$ is known to not present oxidative behavior at the potential range of OER studies [87]. The layered structure of $\mathrm{ZrP}$ makes it possible to study the OER in a confined environment when actives species are intercalated in it. The presence of the Brönsted acid groups $\mathrm{P}-\mathrm{OH}$ at the surface of the nanoparticles, makes it possible to study the reaction at $\mathrm{ZrP}$-modified surfaces. Moreover, $\mathrm{ZrP}$ versatility in controllable synthesis to produce several different morphologies and nanoparticles with different aspect ratios makes it suitable for nanostructuring studies. Nanostructuring $\mathrm{ZrP}$ supporting structures could improve the loading of active species, expose more active sites to the electrolyte and/or 
increase the intrinsic activity of each active site by changes in synergy between the active species and support. In this section, the recent advancements made with $\mathrm{ZrP}$ as an inorganic support for transition metals for the electrocatalysis of the OER will be overviewed.

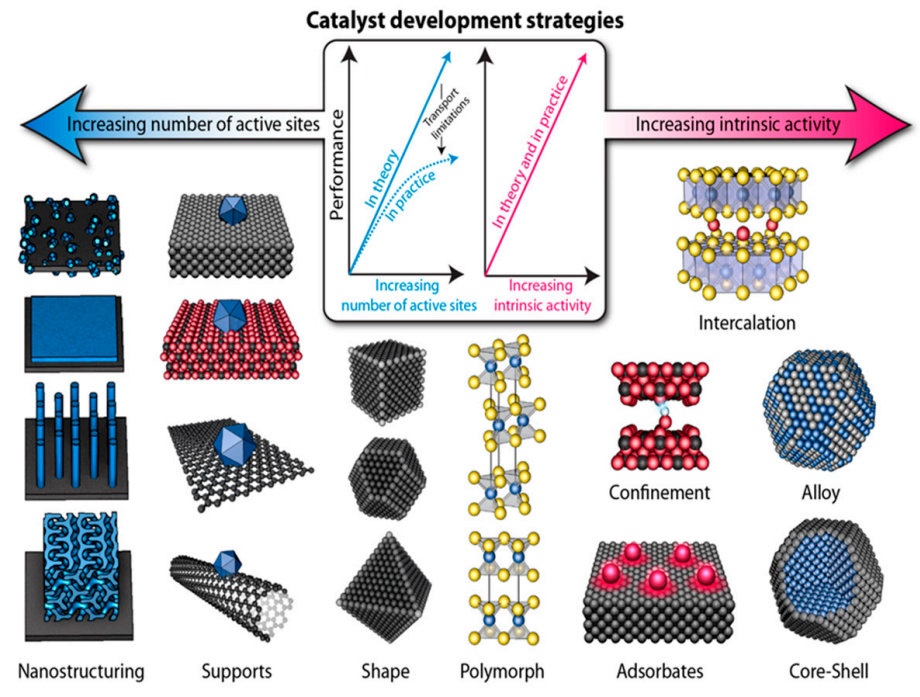

Figure 7. Schematic representation of various catalyst development strategies, which aim to increase the number of active sites and/or increase the intrinsic activity of each site. Reproduced from [86], with permission from the American Association for the Advancement of Science, 2017.

\subsection{Intercalated and Surface Adsorbed Transition Metals ZrP Electrocatalysts}

Sanchez et al. performed the first study of $\mathrm{ZrP}$ as a support for earth-abundant transition metal cations for the OER [87]. On this study, the transition metal cations $\mathrm{Fe}^{2+}, \mathrm{Fe}^{3+}, \mathrm{Co}^{2+}$, and $\mathrm{Ni}^{2+}$ were either intercalated into or adsorbed onto $\alpha$-ZrP. To intercalate the transition metals, the authors utilized the direct ion exchange method developed by Martí and Colón. For this, a suspension of $\theta-\mathrm{ZrP}$ is mixed with a solution of the metal salt precursor and left stirring for several days at room temperature so that ion-exchange reaches equilibrium (Figure 8A). Ion-exchange in ZrP occurs at the Brönsted acid groups which are also present at the surface of the nanoparticles. Hence, there is no way of preventing metal cations adsorbing on the surface. To obtain more insight into the nature of the activity of the samples, a second metal-modified ZrP system in which the metals are only adsorbed onto the surface of the nanoparticles was also prepared. To prepare the surface-adsorbed counterparts, $\alpha-\mathrm{ZrP}$ is used as the $\mathrm{ZrP}$ precursor instead of $\theta-\mathrm{ZrP}$ (Figure $8 \mathrm{~B}$ ). The metal cations are large enough that intercalation into $\alpha-Z r P$ was not observed. Characterization through several methods such as XRPD, Fourier transform infrared spectroscopy (FT-IR), and thermogravimetric analysis (TGA) confirm the successful preparation of both metal-modified ZrP catalytic systems.
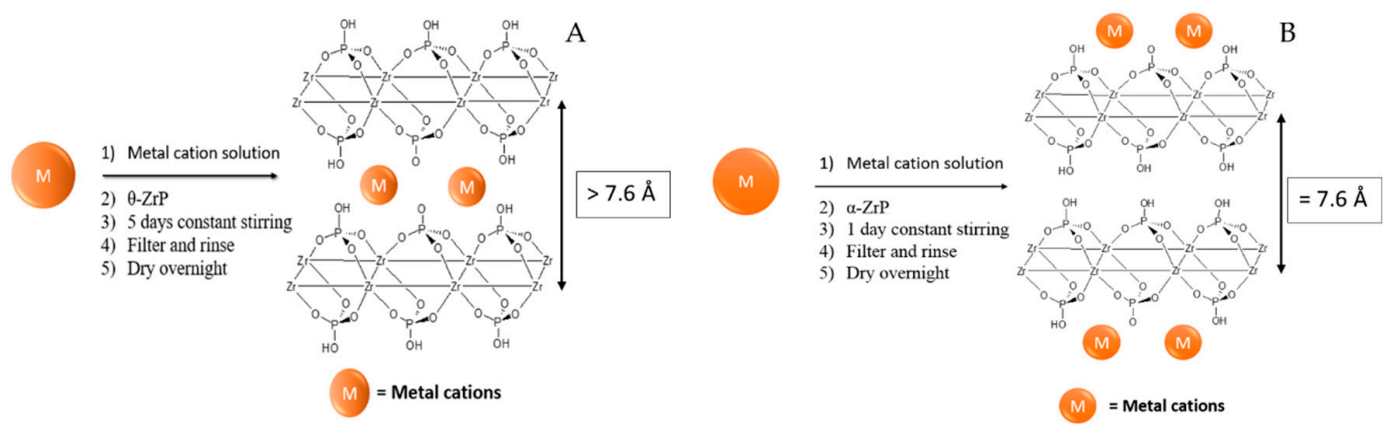

Figure 8. Schematic representation of the preparation procedure of (A) metal-intercalated and (B) surface adsorbed $\mathrm{ZrP}$ catalysts. 
The electrochemical activity towards the OER of these systems was assessed with cyclic volatammetry $(\mathrm{CV})$ experiments using a rotating disk electrode (RDE) in $0.1 \mathrm{M} \mathrm{KOH}$ electrolyte. The OER acitvity was determined from the overpotential necessary to achieve $10 \mathrm{~mA} / \mathrm{cm}^{2}$, as this parameter has been suggested to be used to benchmark OER catalyst activity [84]. The overpotential at a current density of $10 \mathrm{~mA} / \mathrm{cm}^{2}$ is the potential difference between the potential necessary to achieve that current density and the thermodynamic potential of water oxidation (1.23 V vs RHE). All ZrP cataytic systems were active for the OER, requiring between $0.5-0.7 \mathrm{~V}$ of overpotential to reach $10 \mathrm{~mA} / \mathrm{cm}^{2}$. However, the authors observed that, in general, the OER activities for the metal-adsorbed ZrP catalysts are greater than or equal to those of their metal-intercalated counterparts at the same synthesis M:ZrP molar ratios, as seen by their lower overpotentials (Figure 9). This result highlights an important aspect of these systems: the OER occurs preferentially on the outer surfaces of the nanoparticles $[87,88]$. This is deduced from the fact that XPS measurements corroborate that the intercalated catalysts have a higher metal loading than those in which the metals are only adsorbed. Hence, the intercalated species are not electrochemically accessible to perform the OER which the authors hypothetized that it may be due to differences in mass transport and/or electronic conductivity in the two systems.

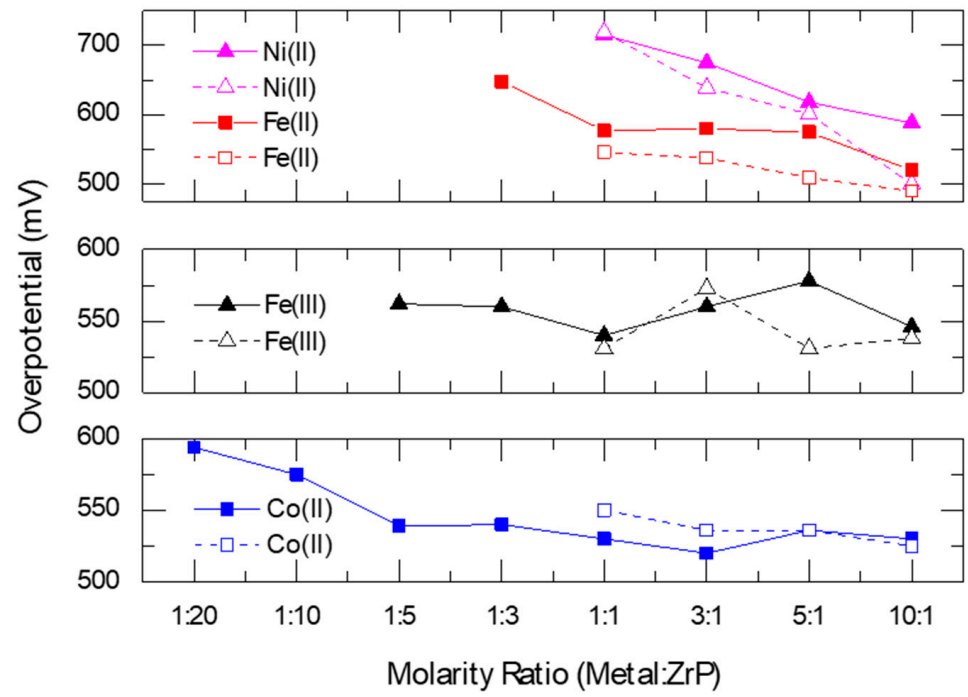

Figure 9. Overpotential as a function of $\mathrm{M}: \mathrm{ZrP}$ synthesis ratio for the different metal-modified $\mathrm{ZrP}$ catalysts. Dashed lines correspond to surface-adsorbed catalysts while the solid line correspond to metal-intercalated catalysts. Taken from reference [87].

\subsection{Exfoliation of ZrP for Improved OER}

Following the previously obtained results in which the OER occurs preferentially on the surface of layered metal-modified ZrP nanoparticles, Ramos-Garcés et al. prepared metal-modified exfoliated $\mathrm{ZrP}$ electrocatalysts [47]. The authors exfoliated $\mathrm{ZrP}$ by using $\mathrm{TBA}^{+} \mathrm{OH}^{-}$as the exfoliating agent and afterwards, did an acid wash with $\mathrm{HCl}$ to obtain $\mathrm{ZrP}$ nanosheets. These nanosheets were subsequently modified with $\mathrm{Co}^{2+}$ and $\mathrm{Ni}^{2+}$ cations at an excess 10:1 M:ZrP molar ratio with the aim of obtaining a maximum metal loading on the systems. They also prepared the previously reported $\mathrm{Co}^{2+}$ and $\mathrm{Ni}^{2+}$ surface-adsorbed $\mathrm{ZrP}$ electrocatalysts at the same excess molar ratio to compare their activity to the novel exfoliated materials.

The activity of these exfoliated nanomaterials was detemined through overpotential, Tafel slope, mass activity, and turnover frequency (TOF) basis. Results show that the exfoliated nanomaterials required less overpotential to achieve the same current density when compared to the surface-adsorbed layered nanoparticles (Figure 10). The intrinsic activity of each catalytic site was probed with mass activity and TOF analyses using the metal loading determined experimentally by inductively coupled plasma-mass spectrometry (ICP-MS). These results show that the lower overpotential of the exfoliated 
samples is due to a larger number of active sites. ICP-MS results show that $\mathrm{ZrP}$ nanosheets are substantially better at adsorbing $\mathrm{Co}^{2+}$ and $\mathrm{Ni}^{2+}$ cations, leading to higher loadings than non-exfoliated ZrP. However, these exfoliated catalysts maintain comparable intrinsic activity to metal-modified layered catalysts, resulting in higher geometric normalized activities due to the significant greater number of actives sites.

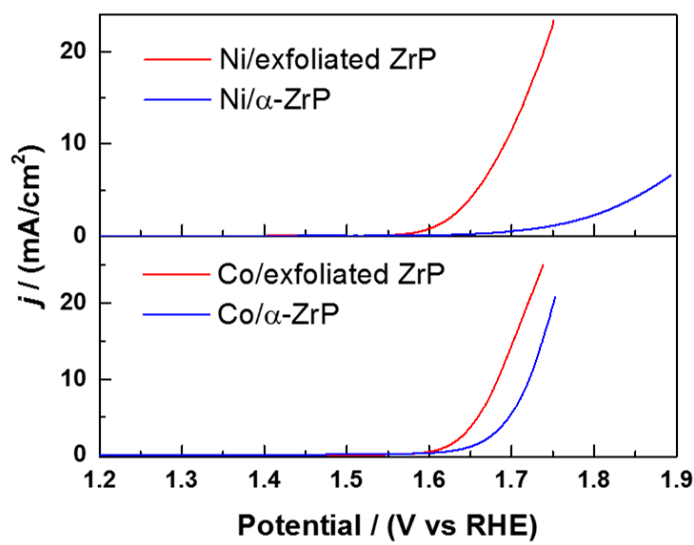

Figure 10. iR-compensated linear sweep voltammograms of Ni-modified and Co-modified ZrP catalysts in 0.1 M KOH. Reproduced from [47], with permission from the American Chemical Society, 2019.

\subsection{Nanostructuring ZrP to Support Transition Metals Species}

Recently, Ramos-Garcés et al. reported the dependence of OER activty on the morphology of the metal-modified $\mathrm{ZrP}$ support [89]. These authors prepared $\mathrm{ZrP}$ materials with different morphologies: rod-like $\mathrm{ZrP}$ using the minimal solvent synthesis method [40], cube-like $\mathrm{ZrP}$ using the alcohol intercalation/deintercalation method [57], mesoporous spheres using the Tarafdar et al. method [60], and $\alpha-\mathrm{ZrP}$ hexagonal platelets obtained from the reflux method. The $\mathrm{ZrP}$ supports with different morphologies were prepared for their use as supports for $\mathrm{Co}^{2+}$ and $\mathrm{Ni}^{2+}$ cations. Figure 11 shows the XRPD patterns of these $\mathrm{ZrP}$ structures [87]. The $\mathrm{ZrP}$ support structures were treated with a large excess (molar ratio) of the metal salt solutions, expecting to obtain similar loadings. However, different loadings were obtained, as evidenced by ICP-MS. Therefore, the number of active species on the surface of the metal-modified $\mathrm{ZrP}$ supports is different for the different morphologies. $\mathrm{Co}^{2+}$ cations exchanged with surface $\mathrm{ZrP}$ protons to a higher level than the $\mathrm{Ni}^{2+}$ cations, regardless of $\mathrm{ZrP}$ morphology. The maximum loading levels followed the trend $\alpha-\mathrm{ZrP}>$ rod-like $\mathrm{ZrP}>$ cube-like $\mathrm{ZrP}$ $>\mathrm{ZrP}$ spheres, indicating that the different particle sizes and crystallinities affect the ion exchange behavior of the $\mathrm{ZrP}$ materials, as previously observed [35,90].

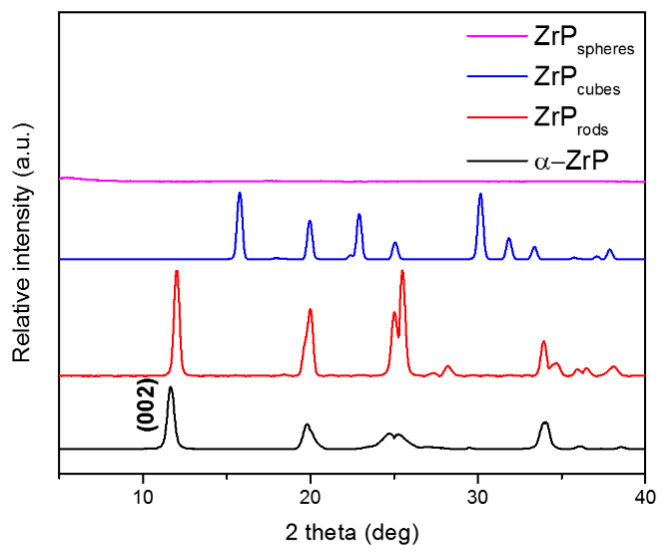

Figure 11. XRPD patterns of $\alpha$-ZrP, rod-like ZrP, cube-like ZrP, and spherical ZrP. [89]—Reproduced by permission from The Royal Society of Chemistry. 
The Co-modified ZrP catalysts show an expected trend in activity, as the activity decreased with a decrease in Co-loading from support to support. The activity decrease was observed in overpotential, Tafel slope, and mass analysis basis. However, this trend is reversed for the Ni-based catalysts. That is, as the Ni content increased, the activity from support to support decreased. This observation was explained by the difference in the surface-area-to-volume-ratio (SA:V) of the different $\mathrm{ZrP}$ supports and the in-plane conductivity of the catalysts. The SA:V was calculated from the average dimensions of the $\mathrm{ZrP}$ structures that were obtained through TEM/STEM. The calculated SA:V for the different $\mathrm{ZrP}$ structures were: $0.07(\alpha-\mathrm{ZrP}), 0.16$ (ZrP rods), 0.034 (ZrP cubes), 0.0039 ( $\mathrm{ZrP}$ spheres).

$\alpha-\mathrm{ZrP}$ and rod-like $\mathrm{ZrP}$, the $\mathrm{ZrP}$ morphologies with higher $\mathrm{SA}: \mathrm{V}$, achieved higher loadings of $\mathrm{Co}^{2+}$ and obtained a higher coverage compared to the other $\mathrm{ZrP}$ morphologies. The higher coverage of cobalt species improved the conductivity of the materials and the electrocatalysis performance. In contrast, the conductivity of the Ni-modified $\mathrm{ZrP}$ catalysts decreased with increased $\mathrm{Ni}^{2+}$ loading. When the SA:V is taken into consideration, it can be deduced that the higher coverage of $\mathrm{Ni}$ species in the $\mathrm{ZrP}$ rods and $\alpha-\mathrm{ZrP}$ leads to abundant resistive nickel species. This results in inactive areas on the surface of the supporting structures due to conductivity issues that can hinder the transport of electrons for the composite catalysts during the OER. Interestingly, the Ni-modified ZrP spheres show a much higher activity compared to the other $\mathrm{ZrP}$ structures. This was explained by the much lower coverage of $\mathrm{Ni}$ species on the micron size particles, and issues with conductivity might be minimized.

The geometric normalized activities of these metal-modified $\mathrm{ZrP}$ materials are considered moderate. However, an analysis of intrinsic activity, such as the mass activity, shows the potential of the $\mathrm{ZrP}$ structures as supports for OER actives species. Table 2 shows the mass activities for the different Metal/ZrP catalysts at an overpotential of $350 \mathrm{mV}$, as well as for the $\mathrm{IrO}_{x}$ catalyst in alkaline electrolyte. These data show that the choice of the $\mathrm{ZrP}$ support tunes the mass activity for the different catalysts. However, it is interesting to note that a low loading $\mathrm{Ni} / \mathrm{ZrP}$ catalyst showcases a mass activity higher than benchmark $\mathrm{IrO}_{\mathrm{x}}$. This highlights the importance of the metal coverage and conductivity for these types of $\mathrm{ZrP}$ catalysts, making these parameters targets for improving their performance.

Table 2. Oxygen evolution reaction (OER) activity observed by mass activity analysis for the different metal-modified $\mathrm{ZrP}$ catalysts and benchmark catalyst $\mathrm{IrO}_{\mathrm{x}}$ in alkaline electrolyte.

\begin{tabular}{cccc}
\hline Metal & ZrP Support & Mass Activity at 1.58 V vs. RHE (A/g) & Reference \\
\hline \multirow{4}{*}{ Co } & $\alpha-$-ZrP & 115 & {$[87]$} \\
& ZrP rods & 4 & {$[87]$} \\
& ZrP cubes & 72 & {$[87]$} \\
& ZrP spheres & 56 & {$[87]$} \\
\hline \multirow{4}{*}{$\mathrm{Ni}$} & $\alpha-Z r P$ & 50 & {$[87]$} \\
& ZrP rods & 85 & {$[87]$} \\
& ZrP cubes & 91 & {$[87]$} \\
& ZrP spheres & 272 & {$[87]$} \\
\hline $\mathrm{IrO}_{\mathrm{x}}$ & - & 257 & {$[91]$} \\
\hline
\end{tabular}

\section{Conclusions}

This review highlights some advancements made in the preparation of $\mathrm{ZrP}$ nanomaterials. This includes the synthesis of $\alpha-\mathrm{ZrP}$ and how the synthesis method may affect its aspect ratio. We also overviewed exfoliation techniques and intercalation chemistry of ZrP. Synthesis strategies that have been explored to produce $\mathrm{ZrP}$ materials with different morphologies were also explored.

This work concludes with an overview of an emerging application of ZrP: supports for metal species for the electrocatalysis of the OER. Advancements to date have shown that conductivity plays an important role in the activity of these catalysts. Moreover, physical factors such as species coverage also need to be considered when trying to improve these systems. Studies with mixed-metal 
systems are underway. We envision that new strategies to improve OER catalysis with $\mathrm{ZrP}$ will show promising results.

Funding: This work was funded by the National Science Foundation under the NSF-PREM Center for Interfacial Electrochemistry of Energy Materials (CIE2M) grant DMR-1827622.

Conflicts of Interest: The authors declare no conflict of interest.

\section{References}

1. Clearfield, A.; Stynes, J.A. The Preparation of Crystalline Zirconium Phosphate and Some Observations on Its Ion Exchange Behaviour. J. Inorg. Nucl. Chem. 1964, 26, 117-129. [CrossRef]

2. Troup, J.M.; Clearfield, A. Mechanism of Ion Exchange in Zirconium Phosphates. 20. Refinement of the Crystal Structure of. Alpha.-Zirconium Phosphate. Inorg. Chem. 1977, 16, 3311-3314. [CrossRef]

3. Clearfield, A.; Smith, G.D. Crystallography and Structure of. Alpha.-Zirconium Bis(Monohydrogen Orthophosphate) Monohydrate. Inorg. Chem. 1969, 8, 431-436. [CrossRef]

4. Clearfield, A.; Blessing, R.H.; Stynes, J.A. New Crystalline Phases of Zirconium Phosphate Possessing Ion-Exchange Properties. J. Inorg. Nucl. Chem. 1968, 30, 2249-2258. [CrossRef]

5. Clearfield, A.; Duax, W.L.; Medina, A.S.; Smith, G.D.; Thomas, J.R. Mechanism of Ion Exchange in Crystalline Zirconium Phosphates. I. Sodium Ion Exchange of. Alpha.-Zirconium Phosphate. J. Phys. Chem. 1969, 73, 3424-3430. [CrossRef]

6. Zhou, Y.; Noshadi, I.; Ding, H.; Liu, J.; Parnas, R.S.; Clearfield, A.; Xiao, M.; Meng, Y.; Sun, L. Solid Acid Catalyst Based on Single-Layer $\alpha$-Zirconium Phosphate Nanosheets for Biodiesel Production via Esterification. Catalysts 2018, 8, 17. [CrossRef]

7. Pica, M. Zirconium Phosphate Catalysts in the XXI Century: State of the Art from 2010 to Date. Catalysts 2017, 7, 190. [CrossRef]

8. Cheng, Y.; Chuah, G.K. The Synthesis and Applications of $\alpha$-Zirconium Phosphate. Chin. Chem. Lett. 2020, 31, 307-310. [CrossRef]

9. González-Villegas, J.; Kan, Y.; Bakhmutov, V.I.; García-Vargas, A.; Martínez, M.; Clearfield, A.; Colón, J.L. Poly(Ethylene Glycol)-Modified Zirconium Phosphate Nanoplatelets for Improved Doxorubicin Delivery. Inorg. Chim. Acta 2017, 468, 270-279. [CrossRef]

10. Cruz, E.; Broker, E.J.; Mosby, B.M. Combination of Intercalation and Surface Modification in Layered Zirconium Phosphates: Investigation of Surface Stability and Reactivity. Dalton Trans. 2020. [CrossRef] [PubMed]

11. Díaz, A.; Mosby, B.M.; Bakhmutov, V.I.; Martí, A.A.; Batteas, J.D.; Clearfield, A. Self-Assembled Monolayers Based Upon a Zirconium Phosphate Platform. Chem. Mater. 2013, 25, 723-728. [CrossRef]

12. Pica, M.; Nocchetti, M.; Ridolfi, B.; Donnadio, A.; Costantino, F.; Gentili, P.L.; Casciola, M. Nanosized Zirconium Phosphate/AgCl Composite Materials: A New Synergy for Efficient Photocatalytic Degradation of Organic Dye Pollutants. J. Mater. Chem. A 2015, 3, 5525-5534. [CrossRef]

13. Martí, A.A.; Colón, J.L. Direct Ion Exchange of Tris(2,2'-Bipyridine)Ruthenium(II) into an $\alpha$-Zirconium Phosphate Framework. Inorg. Chem. 2003, 42, 2830-2832. [CrossRef] [PubMed]

14. Casañas-Montes, B.; Díaz, A.; Barbosa, C.; Ramos, C.; Collazo, C.; Meléndez, E.; Queffelec, C.; Fayon, F.; Clearfield, A.; Bujoli, B.; et al. Molybdocene Dichloride Intercalation into Zirconium Phosphate Nanoparticles. J. Organomet. Chem. 2015, 791, 34-40. [CrossRef]

15. Díaz, A.; David, A.; Pérez, R.; González, M.L.; Báez, A.; Wark, S.E.; Zhang, P.; Clearfield, A.; Colón, J.L. Nanoencapsulation of Insulin into Zirconium Phosphate for Oral Delivery Applications. Biomacromolecules 2010, 11, 2465-2470. [CrossRef]

16. Díaz, A.; Saxena, V.; González, J.; David, A.; Casañas, B.; Carpenter, C.; Batteas, J.D.; Colón, J.L.; Clearfield, A.; Hussain, M.D. Zirconium Phosphate Nano-Platelets: A Novel Platform for Drug Delivery in Cancer Therapy. Chem. Commun. 2012, 48, 1754-1756. [CrossRef]

17. Díaz, A.; González, M.L.; Pérez, R.J.; David, A.; Mukherjee, A.; Báez, A.; Clearfield, A.; Colón, J.L. Direct Intercalation of Cisplatin into Zirconium Phosphate Nanoplatelets for Potential Cancer Nanotherapy. Nanoscale 2013, 5, 11456-11463. [CrossRef] 
18. Santiago, M.B.; Vélez, M.M.; Borrero, S.; Díaz, A.; Casillas, C.A.; Hofmann, C.; Guadalupe, A.R.; Colón, J.L. NADH Electrooxidation Using Bis(1,10-Phenanthroline-5,6-Dione)(2,2'-Bipyridine)Ruthenium(II)Exchanged Zirconium Phosphate Modified Carbon Paste Electrodes. Electroanalysis 2006, 18, 559-572. [CrossRef]

19. Santiago, M.B.; Declet-Flores, C.; Díaz, A.; Vélez, M.M.; Bosques, M.Z.; Sanakis, Y.; Colón, J.L. Layered Inorganic Materials as Redox Agents: Ferrocenium-Intercalated Zirconium Phosphate. Langmuir 2007, 23, 7810-7817. [CrossRef]

20. Santiago, M.B.; Daniel, G.A.; David, A.; Casañas, B.; Hernández, G.; Guadalupe, A.R.; Colón, J.L. Effect of Enzyme and Cofactor Immobilization on the Response of Ethanol Oxidation in Zirconium Phosphate Modified Biosensors. Electroanalysis 2010, 22, 1097-1105. [CrossRef]

21. Zhou, Y.; Huang, R.; Ding, F.; Brittain, A.D.; Liu, J.; Zhang, M.; Xiao, M.; Meng, Y.; Sun, L. Sulfonic Acid-Functionalized $\alpha$-Zirconium Phosphate Single-Layer Nanosheets as a Strong Solid Acid for Heterogeneous Catalysis Applications. ACS Appl. Mater. Interfaces 2014, 6, 7417-7425. [CrossRef]

22. Clearfield, A.; Thakur, D.S. Zirconium and Titanium Phosphates as Catalysts: A Review. Appl. Catal. 1986, 26, 1-26. [CrossRef]

23. Hajipour, A.R.; Karimi, H. Zirconium Phosphate Nanoparticles as a Remarkable Solid Acid Catalyst for Selective Solvent-Free Alkylation of Phenol. Chin. J. Catal. 2014, 35, 1136-1147. [CrossRef]

24. Niño, M.E.; Giraldo, S.A.; Páez-Mozo, E.A. Olefin Oxidation with Dioxygen Catalyzed by Porphyrins and Phthalocyanines Intercalated in $\alpha$-Zirconium Phosphate. J. Mol. Catal. Chem. 2001, 175, 139-151. [CrossRef]

25. Clearfield, A. Group IV Phosphates as Catalysts and Catalyst Supports. J. Mol. Catal. 1984, 27, $251-262$. [CrossRef]

26. Hajipour, A.R.; Karimi, H. Zinc Zirconium Phosphate as an Efficient Catalyst for Chemoselective Synthesis of 1,1-diacetates under Solvent-free Conditions. J. Chem. Sci. 2015, 127, 1945-1955. [CrossRef]

27. Alongi, J.; Frache, A. Flame Retardancy Properties of $\alpha$-Zirconium Phosphate Based Composites. Polym. Degrad. Stab. 2010, 95, 1928-1933. [CrossRef]

28. Xiao, Y.; Xu, J.; Huang, S.; Deng, H. Effects of $\alpha-Z r P$ on Crystallinity and Flame-Retardant Behaviors of PA6/MCA Composites. Int. J. Polym. Sci. 2017, 2017, 6034741. [CrossRef]

29. Xu, W.; Li, W.; Wang, X.; Zhang, X.; Cheng, Z. Effect of Different Ionic Layered Compounds Decorated with Zinc Hydroxystannate on Flame Retardancy and Smoke Performance of Epoxy Resin. Polym. Adv. Technol. 2019, 31, 731-740. [CrossRef]

30. Laipan, M.; Xiang, L.; Yu, J.; Martin, B.R.; Zhu, R.; Zhu, J.; He, H.; Clearfield, A.; Sun, L. Layered Intercalation Compounds: Mechanisms, New Methodologies, and Advanced Applications. Prog. Mater. Sci. 2020, 109, 100631. [CrossRef]

31. Xiao, H.; Liu, S. Zirconium Phosphate (ZrP)-Based Functional Materials: Synthesis, Properties and Applications. Mater. Des. 2018, 155, 19-35. [CrossRef]

32. Alberti, G.; Torracca, E. Crystalline Insoluble Salts of Polybasic Metals-II. Synthesis of Crystalline Zirconium or Titanium Phosphate by Direct Precipitation. J. Inorg. Nucl. Chem. 1968, 30, 317-318. [CrossRef]

33. Shuai, M.; Mejia, A.F.; Chang, Y.-W.; Cheng, Z. Hydrothermal Synthesis of Layered $\alpha$-Zirconium Phosphate Disks: Control of Aspect Ratio and Polydispersity for Nano-Architecture. CrystEngComm 2013, 15, 1970. [CrossRef]

34. Sun, L.; Boo, W.J.; Sue, H.-J.; Clearfield, A. Preparation of $\alpha$-Zirconium Phosphate Nanoplatelets with Wide Variations in Aspect Ratios. New J. Chem. 2007, 31, 39-43. [CrossRef]

35. Contreras-Ramirez, A.; Tao, S.; Day, G.S.; Bakhmutov, V.I.; Billinge, S.J.L.; Zhou, H.-C. Zirconium Phosphate: The Pathway from Turbostratic Disorder to Crystallinity. Inorg. Chem. 2019, 58, 14260-14274. [CrossRef]

36. Horsley, S.E.; Nowell, D.V. The Preparation and Characterisation of Crystalline $\alpha$-Zirconium Phosphate. J. Appl. Chem. Biotechnol. 1973, 23, 215-224. [CrossRef]

37. Capitani, D.; Casciola, M.; Donnadio, A.; Vivani, R. High Yield Precipitation of Crystalline $\alpha$-Zirconium Phosphate from Oxalic Acid Solutions. Inorg. Chem. 2010, 49, 9409-9415. [CrossRef]

38. Tahara, S.; Takakura, Y.; Sugahara, Y. Preparation of $\alpha$-Zirconium Phosphate from Fluorozirconate and Phosphoric Acid by Liquid-Phase Deposition. Chem. Lett. 2012, 41, 555-557. [CrossRef]

39. Pica, M.; Donnadio, A.; Capitani, D.; Vivani, R.; Troni, E.; Casciola, M. Advances in the Chemistry of Nanosized Zirconium Phosphates: A New Mild and Quick Route to the Synthesis of Nanocrystals. Inorg. Chem. 2011, 50, 11623-11630. [CrossRef] 
40. Cheng, Y.; Wang, X.T.; Jaenicke, S.; Chuah, G.-K. Minimalistic Liquid-Assisted Route to Highly Crystalline $\alpha$-Zirconium Phosphate. ChemSusChem 2017, 10, 3235-3242. [CrossRef]

41. Tao, H.; Zhang, Y.; Gao, Y.; Sun, Z.; Yan, C.; Texter, J. Scalable Exfoliation and Dispersion of Two-Dimensional Materials-An Update. Phys. Chem. Chem. Phys. 2017, 19, 921-960. [CrossRef] [PubMed]

42. Cai, X.; Luo, Y.; Liu, B.; Cheng, H.-M. Preparation of 2D Material Dispersions and Their Applications. Chem. Soc. Rev. 2018, 47, 6224-6266. [CrossRef] [PubMed]

43. Wang, L.; Xu, W.-H.; Yang, R.; Zhou, T.; Hou, D.; Zheng, X.; Liu, J.-H.; Huang, X.-J. Electrochemical and Density Functional Theory Investigation on High Selectivity and Sensitivity of Exfoliated Nano-Zirconium Phosphate toward Lead(II). Anal. Chem. 2013, 85, 3984-3990. [CrossRef] [PubMed]

44. Sun, L.; Boo, W.J.; Sun, D.; Clearfield, A.; Sue, H.-J. Preparation of Exfoliated Epoxy/ $\alpha$-Zirconium Phosphate Nanocomposites Containing High Aspect Ratio Nanoplatelets. Chem. Mater. 2007, 19, 1749-1754. [CrossRef]

45. Aoyama, Y.; Fujimura, T.; Sasai, R. Preparation of $\alpha$-Zirconium Phosphate Nanosheet Stacked Solid Films with High Transparency and Intercalating with Cationic Free-Base Porphyrins. Chem. Lett. 2019, 48, 40-42. [CrossRef]

46. Casciola, M.; Alberti, G.; Donnadio, A.; Pica, M.; Marmottini, F.; Bottino, A.; Piaggio, P. Gels of Zirconium Phosphate in Organic Solvents and Their Use for the Preparation of Polymeric Nanocomposites. J. Mater. Chem. 2005, 15, 4262-4267. [CrossRef]

47. Ramos-Garcés, M.V.; Sanchez, J.; Del Toro-Pedrosa, D.E.; Alvarez, I.B.; Wu, Y.; Valle, E.; Villagrán, D.; Jaramillo, T.F.; Colón, J.L. Transition Metal-Modified Exfoliated Zirconium Phosphate as an Electrocatalyst for the Oxygen Evolution Reaction. ACS Appl. Energy Mater. 2019, 2, 3561-3567. [CrossRef]

48. Huang, H.; Li, M.; Tian, Y.; Xie, Y.; Sheng, X.; Jiang, X.; Zhang, X. Exfoliation and Functionalization of $\alpha$-Zirconium Phosphate in One Pot for Waterborne Epoxy Coatings with Enhanced Anticorrosion Performance. Prog. Org. Coat. 2020, 138, 105390. [CrossRef]

49. Zhou, Y.; Ding, H.; Liu, J.; LaChance, A.M.; Xiao, M.; Meng, Y.; Sun, L. Gold Nanoparticles Immobilized on Single-Layer $\alpha$-Zirconium Phosphate Nanosheets as a Highly Effective Heterogeneous Catalyst. Adv. Compos. Hybrid Mater. 2019, 2, 520-529. [CrossRef]

50. Campoccia, D.; Ravaioli, S.; Vivani, R.; Donnadio, A.; Vischini, E.; Russo, A.; Visai, L.; Arciola, C.R.; Montanaro, L.; Nocchetti, M. Antibacterial Properties of a Novel Zirconium Phosphate-Glycinediphosphonate Loaded with Either Zinc or Silver. Materials 2019, 12, 3184. [CrossRef]

51. Kim, H.-N.; Keller, S.W.; Mallouk, T.E.; Schmitt, J.; Decher, G. Characterization of Zirconium Phosphate/Polycation Thin Films Grown by Sequential Adsorption Reactions. Chem. Mater. 1997, 9 , 1414-1421. [CrossRef]

52. Kaschak, D.M.; Johnson, S.A.; Hooks, D.E.; Kim, H.-N.; Ward, M.D.; Mallouk, T.E. Chemistry on the Edge: A Microscopic Analysis of the Intercalation, Exfoliation, Edge Functionalization, and Monolayer Surface Tiling Reactions of $\alpha$-Zirconium Phosphate. J. Am. Chem. Soc. 1998, 120, 10887-10894. [CrossRef]

53. Chen, L.; Sun, D.; Li, J.; Zhu, G. Exfoliation of Layered Zirconium Phosphate Nanoplatelets by Melt Compounding. Mater. Des. 2017, 122, 247-254. [CrossRef]

54. Xia, F.; Yong, H.; Han, X.; Sun, D. Small Molecule-Assisted Exfoliation of Layered Zirconium Phosphate Nanoplatelets by Ionic Liquids. Nanoscale Res. Lett. 2016, 11, 348. [CrossRef] [PubMed]

55. Lin, X.; Schmelter, D.; Imanian, S.; Hintze-Bruening, H. Hierarchically Ordered $\alpha$-Zirconium Phosphate Platelets in Aqueous Phase with Empty Liquid. Sci. Rep. 2019, 9, 16389. [CrossRef]

56. White, K.L.; Li, P.; Yao, H.; Nishimura, R.; Sue, H.-J. Effect of Surface Modifier on Flow Properties of Epoxy Suspensions Containing Model Plate-like Nanoparticles. Rheol. Acta 2014, 53, 571-583. [CrossRef]

57. Pica, M.; Vivani, R.; Donnadio, A.; Troni, E.; Fop, S.; Casciola, M. Small Is Beautiful: The Unusual Transformation of Nanocrystalline Layered $\alpha$-Zirconium Phosphate into a New 3D Structure. Inorg. Chem. 2015, 54, 9146-9153. [CrossRef]

58. Hashimoto, C.; Nakajima, Y.; Terada, T.; Itoh, K.; Nakayama, S. Effect of the Preparation Conditions of Zirconium Phosphate on the Characteristics of Sr Immobilization. J. Nucl. Mater. 2011, 408, 231-235. [CrossRef]

59. Zhang, F.; Xie, Y.; Lu, W.; Wang, X.; Xu, S.; Lei, X. Preparation of Microspherical $\alpha$-Zirconium Phosphate Catalysts for Conversion of Fatty Acid Methyl Esters to Monoethanolamides. J. Colloid Interface Sci. 2010, 349, 571-577. [CrossRef]

60. Tarafdar, A.; Panda, A.B.; Pradhan, N.C.; Pramanik, P. Synthesis of Spherical Mesostructured Zirconium Phosphate with Acidic Properties. Microporous Mesoporous Mater. 2006, 95, 360-365. [CrossRef] 
61. Bashir, A.; Malik, L.A.; Dar, G.N.; Pandith, A.H. Microwave-Assisted Hydrothermal Synthesis of Agglomerated Spherical Zirconium Phosphate for Removal of $\mathrm{Cs}^{+}$and $\mathrm{Sr}^{2+}$ Ions from Aqueous System. In Applications in Ion Exchange Materials in the Environment; Ahamed, M., Asiri, A., Eds.; Springer: Basel, Switzerland, 2019; pp. 95-108. [CrossRef]

62. Mu, W.; Yu, Q.; Zhang, R.; Li, X.; Hu, R.; He, Y.; Wei, H.; Jian, Y.; Yang, Y. Controlled Fabrication of Flower-like $\alpha$-Zirconium Phosphate for the Efficient Removal of Radioactive Strontium from Acidic Nuclear Wastewater. J. Mater. Chem. A 2017, 5, 24388-24395. [CrossRef]

63. Yu, J.; Ding, H.; Lampron, J.; Martin, B.R.; Clearfield, A.; Sun, L. Complexing Agent Directed Growth of $\alpha$-Zirconium Phosphate-Based Hexagonal Prisms. Inorg. Chem. 2020, 59, 1204-1210. [CrossRef] [PubMed]

64. Hu, X.; Li, R.; Xing, Y. Simple One-Step Synthesis of Coil-like Cobalt Zirconium Phosphate Microspheres and the Application as Photocatalysts. Mater. Lett. 2020, 264, 127299. [CrossRef]

65. Feng, Y.; He, W.; Zhang, X.; Jia, X.; Zhao, H. The Preparation of Nanoparticle Zirconium Phosphate. Mater. Lett. 2007, 61, 3258-3261. [CrossRef]

66. Whittingham, M.S. Intercalation Chemistry: An Introduction. In Intercalation Chemistry; Whittingham, M.S., Jacobson, A.J., Eds.; Academic Press: New York, NY, USA, 1982; pp. 1-18. [CrossRef]

67. Alberti, G.; Costantino, U.; Gupta, J.P. Crystalline Insoluble Acid Salts of Tetravalent Metals-XIX: $\mathrm{Na}^{+}$-Catalyzed $\mathrm{H}^{+}-\mathrm{Mg}^{2+}$ and $\mathrm{H}^{+}-\mathrm{Cs}^{+}$Ion Exchanges on $\alpha$-Zirconium Phosphate. J. Inorg. Nucl. Chem. 1974, 36, 2109-2114. [CrossRef]

68. Alberti, G.; Bertrami, R.; Costantino, U. Crystalline Insoluble Acid Salts of Tetravalent Metals-XXII: Effect of Small Amounts of $\mathrm{Na}^{+}$on the Ion Exchange of Alkaline Earth Metal Ions on Crystalline $\mathrm{Zr}\left(\mathrm{HPO}_{4}\right)_{2} \cdot \mathrm{H}_{2} \mathrm{O}$. J. Inorg. Nucl. Chem. 1976, 38, 1729-1732. [CrossRef]

69. Alberti, G.; Costantino, U. Recent Progress in the Intercalation Chemistry of Layered $\alpha$-Zirconium Phosphate and Its Derivatives, and Future Perspectives for Their Use in Catalysis. J. Mol. Catal. 1984, 27, 235-250. [CrossRef]

70. Clearfield, A.; Tindwa, R.M. On the Mechanism of Ion Exchange in Zirconium Phosphates-XXI Intercalation of Amines by $\alpha$-Zirconium Phosphate. J. Inorg. Nucl. Chem. 1979, 41, 871-878. [CrossRef]

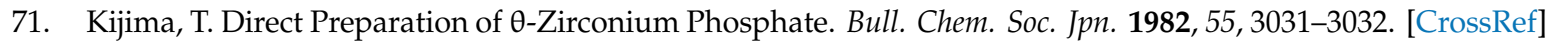

72. Alberti, G.; Costantino, U.; Gill, J.S. Crystalline Insoluble Acid Salts of Tetravalent Metals—XXIII: Preparation and Main Ion Exchange Properties of Highly Hydrated Zirconium Bis Monohydrogen Orthophosphates. J. Inorg. Nucl. Chem. 1976, 38, 1733-1738. [CrossRef]

73. Sun, L.; O'Reilly, J.Y.; Kong, D.; Su, J.Y.; Boo, W.J.; Sue, H.-J.; Clearfield, A. The Effect of Guest Molecular Architecture and Host Crystallinity upon the Mechanism of the Intercalation Reaction. J. Colloid Interface Sci. 2009, 333, 503-509. [CrossRef]

74. Hu, H.; Martin, J.C.; Zhang, M.; Southworth, C.S.; Xiao, M.; Meng, Y.; Sun, L. Immobilization of Ionic Liquids in $\theta$-Zirconium Phosphate for Catalyzing the Coupling of $\mathrm{CO}_{2}$ and Epoxides. RSC Adv. 2012, 2, 3810-3815. [CrossRef]

75. Wen, M.; Mori, K.; Kuwahara, Y.; Yamashita, H. Visible-Light-Responsive Carbon Dioxide Reduction System: Rhenium Complex Intercalated into a Zirconium Phosphate Layered Matrix. ChemCatChem 2015, 7, 3519-3525. [CrossRef]

76. Rivera, E.J.; Barbosa, C.; Torres, R.; Rivera, H.; Fachini, E.R.; Green, T.W.; Connick, W.B.; Colón, J.L. Luminescence Rigidochromism and Redox Chemistry of Pyrazolate-Bridged Binuclear Platinum(II) Diimine Complex Intercalated into Zirconium Phosphate Layers. Inorg. Chem. 2012, 51, 2777-2784. [CrossRef]

77. Rivera, E.J.; Barbosa, C.; Torres, R.; Grove, L.; Taylor, S.; Connick, W.B.; Clearfield, A.; Colón, J.L. Vapochromic and Vapoluminescent Response of Materials Based on Platinum(II) Complexes Intercalated into Layered Zirconium Phosphate. J. Mater. Chem. 2011, 21, 15899-15902. [CrossRef]

78. Saxena, V.; Diaz, A.; Clearfield, A.; Batteas, J.D.; Hussain, M.D. Zirconium Phosphate Nanoplatelets: A Biocompatible Nanomaterial for Drug Delivery to Cancer. Nanoscale 2013, 5, 2328-2336. [CrossRef]

79. González, M.L.; Ortiz, M.; Hernández, C.; Cabán, J.; Rodríguez, A.; Colón, J.L.; Báez, A. Zirconium Phosphate Nanoplatelet Potential for Anticancer Drug Delivery Applications. J. Nanosci. Nanotechnol. 2016, 16, 117-129. [CrossRef]

80. Song, F.; Bai, L.; Moysiadou, A.; Lee, S.; Hu, C.; Liardet, L.; Hu, X. Transition Metal Oxides as Electrocatalysts for the Oxygen Evolution Reaction in Alkaline Solutions: An Application-Inspired Renaissance. J. Am. Chem. Soc. 2018, 140, 7748-7759. [CrossRef] 
81. Montoya, J.H.; Seitz, L.C.; Chakthranont, P.; Vojvodic, A.; Jaramillo, T.F.; Nørskov, J.K. Materials for Solar Fuels and Chemicals. Nat. Mater. 2017, 16, 70-81. [CrossRef]

82. Jiao, Y.; Zheng, Y.; Jaroniec, M.; Qiao, S.Z. Design of Electrocatalysts for Oxygen- and Hydrogen-Involving Energy Conversion Reactions. Chem. Soc. Rev. 2015, 44, 2060-2086. [CrossRef]

83. McCrory, C.C.L.; Jung, S.; Peters, J.C.; Jaramillo, T.F. Benchmarking Heterogeneous Electrocatalysts for the Oxygen Evolution Reaction. J. Am. Chem. Soc. 2013, 135, 16977-16987. [CrossRef]

84. McCrory, C.C.L.; Jung, S.; Ferrer, I.M.; Chatman, S.M.; Peters, J.C.; Jaramillo, T.F. Benchmarking Hydrogen Evolving Reaction and Oxygen Evolving Reaction Electrocatalysts for Solar Water Splitting Devices. J. Am. Chem. Soc. 2015, 137, 4347-4357. [CrossRef]

85. Jung, S.; McCrory, C.C.L.; Ferrer, I.M.; Peters, J.C.; Jaramillo, T.F. Benchmarking Nanoparticulate Metal Oxide Electrocatalysts for the Alkaline Water Oxidation Reaction. J. Mater. Chem. A 2016, 4, 3068-3076. [CrossRef]

86. Seh, Z.W.; Kibsgaard, J.; Dickens, C.F.; Chorkendorff, I.; Nørskov, J.K.; Jaramillo, T.F. Combining Theory and Experiment in Electrocatalysis: Insights into Materials Design. Science 2017, 355, eaad4998. [CrossRef]

87. Sanchez, J.; Ramos-Garcés, M.V.; Narkeviciute, I.; Colón, J.L.; Jaramillo, T.F. Transition Metal-Modified Zirconium Phosphate Electrocatalysts for the Oxygen Evolution Reaction. Catalysts 2017, 7, 132. [CrossRef]

88. Ramos-Garcés, M.V.; Sanchez, J.; Barraza Alvarez, I.; Wu, Y.; Villagrán, D.; Jaramillo, T.F.; Colón, J.L. Water Splitting Electrocatalysis within Layered Inorganic Nanomaterials. In Water Chemistry; Eyvaz, M., Yüksel, E., Eds.; IntechOpen: London, UK, 2020. [CrossRef]

89. Ramos-Garcés, M.V.; Sanchez, J.; Luz-Rivera, K.L.; Toro-Pedrosa, D.E.D.; Jaramillo, T.F.; Colón, J.L. Morphology Control of Metal-Modified Zirconium Phosphate Support Structures for the Oxygen Evolution Reaction. Dalton Trans. 2020. [CrossRef]

90. Clearfield, A. Inorganic Ion Exchangers with Layered Structures. Annu. Rev. Mater. Sci. 1984, 14, $205-229$. [CrossRef]

91. Xu, D.; Stevens, M.; Cosby, M.; Oener, S.Z.; Smith, A.; Enman, L.J.; Ayers, K.E.; Capuano, C.B.; Renner, J.; Danilovic, N.; et al. Earth-Abundant Oxygen Electrocatalysts for Alkaline Anion-Exchange-Membrane Water Electrolysis: Effects of Catalyst Conductivity and Comparison with Performance in Three-Electrode Cells. ACS Catal. 2019, 9, 7-15. [CrossRef]

(C) 2020 by the authors. Licensee MDPI, Basel, Switzerland. This article is an open access article distributed under the terms and conditions of the Creative Commons Attribution (CC BY) license (http://creativecommons.org/licenses/by/4.0/). 